\title{
Chapter 10 \\ Identity Game for Welfare: Circumventing Surveillance of Legal Migrants in Europe
}

\author{
Veronika Nagy
}

Based on a critical ethnographic research, this paper aims to reflect on the role of welfare surveillance and outsourced social services in migration procedures of Central European Roma. After the fifth EU Enlargement in 2007, transnational mobility has become a significant challenge for all western governments. As full EU citizens, large Roma populations now enjoy freedom of movement in Europe. The long standing prejudiced perception of Roma as profiteers unwilling to integrate became a basis for concerns about a "threatening flood" of Roma westward. As a result, several old Member States have introduced different control strategies allegedly to ensure security, legitimating excessive policing and surveillance of migrants in order to isolate them from national consensus. The "mechanisms" applied for sorting and excluding unwanted Roma communities are grounded in a set of punitive rules enacted through national and local legislation with the purpose of expulsion. Accordingly, limiting access to social services gradually replaced migration policies as a new process of selection regarding undesired European migrants from A8 countries. Service providers in the neoliberal bureaucratic social fields introduced new modalities of surveillance and restrictions to deny income assistance, benefit entitlement and legal aid. This chapter provides an empirical analysis on the effects of these sorting measures and on how the targeted groups either comply or circumnavigate these regulations in London.

\footnotetext{
V. Nagy $(\bowtie)$

School of Law, Willem Pompe Institute for Criminal Law and Criminology, Utrecht University, Utrecht, The Netherlands

e-mail:v.nagy@uu.nl 


\subsection{Introduction}

Based on a critical ethnographic research, this paper aims to reflect on the role of welfare surveillance and outsourced social services in migration procedures of Central European Roma. After the fifth EU Enlargement in 2007, transnational mobility has become a significant challenge for all western governments. As full EU citizens, large Roma populations now enjoy freedom of movement in Europe. The long standing prejudiced perception of Roma as profiteers unwilling to integrate became a basis for concerns about a "threatening flood" of Roma westward. As a result, several old Member States have introduced different control strategies allegedly to ensure security, legitimating excessive policing and surveillance of migrants in order to isolate them from national consensus. The "mechanisms" applied for sorting and excluding unwanted Roma communities are grounded in a set of punitive rules enacted through national and local legislation with the purpose of expulsion. Accordingly, limiting access to social services gradually replaced migration policies as a new process of selection regarding undesired European migrants from A8 countries. Service providers in the neoliberal bureaucratic social fields introduced new modalities of surveillance and restrictions to deny income assistance, benefit entitlement and legal aid. This chapter provides an empirical analysis on the effects of these sorting measures and on how the targeted groups either comply or circumnavigate these regulations in London.

Theresa Mays' promise to "use Brexit to stop EU migrants claiming UK benefits" (Siobhan 2017), symbolises the populist, exclusionist welfare discourse of the last decade. In response to fears about an increasing influx of Central and Eastern European (CEE) migrants who may be entitled to welfare benefits, several EU member states have extended their border protection and devised internal controls measures that are implemented though local bureaucracies. As mobility across EU member states intensifies, threatening stereotypes associated with non-EU migrants are accompanied by a "new menace": criminal "insiders" or benefit tourists from new member states who might profit from the freedom of mobility within the EU.

The long-standing perception of Roma as profiteers who are involved in illegal activities, live off of welfare and are unwilling to integrate has triggered concerns about a "threatening flood" of westward Roma mobility. This fear has been used to justify new surveillance measures aimed at controlling and profiling unattractive migrant groups. Although the securitisation of Roma migrants is not a new phenomenon, methods of targeting and selecting "undesired citizens" are being increasingly applied as financial aptitudes become the core parameters of migration. When the EU integration agenda led to stricter national migration policies, ${ }^{1}$ the transnational mobility of EU citizens became a security question (Huysmans 2000) presented in terms of financial and cultural threat. Accordingly, the securitisation of Roma migrants has become a part of "a wider politicisation in which immigrants are portrayed as a challenge to the protection of national identity and welfare provisions"

\footnotetext{
${ }^{1}$ See EU legislation COM(2005) 389, ANNEX 16.
} 
(ibid.: 751). These concerns have been used to justify new restrictive measures for profiling the immoral foreign opportunist versus the decent migrant who deserves state support and protection (Erjavec 2001: 703). Although references to "Roma benefit tourism" have been regularly used to justify new control measures, social security screenings and immigration policies are increasingly intertwined within surveillance practices of member states, targeting all unemployed newcomers. This chapter aims to present how the digitalisation of administrative services in the United Kingdom contributes to new discriminatory practices based on financial profiles.

Unemployed migrants are increasingly controlled and sanctioned by British welfare services and subjected to new monitoring practices. However, instead of leaving or avoiding these service providers, many people stay and try to anticipate these financial screening measures. As they increase their knowledge about the data collection methods service providers use, they learn and invent tactics to circumvent benefit restrictions. I will argue that similarities between surveillance profiles used by HM Revenue and Customs (HMRC) and the parameters of ethnic differentiation experienced by CEE Roma in their sending countries have led Roma migrants to interpret welfare exclusion as ethnic discrimination in London and respond to it accordingly. Therefore, while tax surveillance profiles do not include ethnic references, they are defined in terms of the financial sustainability of UK residents, which results in new exclusionary processes.

To recognise how these welfare-service-based financial monitoring structures facilitate migration control, we first need to understand how digitalised bureaucratic incentives (e.g. HMRC screening algorithms and financial sanctions) are used to make undesired groups voluntarily leave or become self-sustaining in the UK. This social sorting process is shaped by political, academic and NGO narratives, in which the economic and ethnic characteristics of migrants are regularly intertwined in references to poor migrants and marginalised unemployed Roma (Cherkezova and Tomova 2013).

First, I will reflect on how benefit applicants are monitored and profiled for welfare eligibility. Second, I will explore how this securitisation process implemented through financial sanctions is fuelled by different stakeholders. Third, I will describe how benefit applicants use strategies to challenge these social services surveillance mechanisms within the "virtual walls" of Fortress Europe. The selected cases of CEE Roma migrants will illustrate the interplay between the digitalised bureaucracies of HMRC welfare providers and the counter surveillance strategies adopted by CEE applicants. Finally, I will describe how the digital gap in online application systems creates a new governance from a distance, in which Roma migrants are not subjected to discrimination because of their ethnic identity but because of their economic profile based on a documented labour history.

Following the critical criminological tradition of qualitative data analyses, this research is based on 18 months of fieldwork performed within various CEE Roma communities (Polish, Slovakian, Hungarian, Czech) in London (Nagy 2018). The research relied on multi-sited ethnography, including institutional and virtual ethnographic tools. Research techniques involved participant observation, inter- 
views and shadowing. As a researcher, interpreter, housemate, "advocacy worker" and ethnographer, I adopted different, often conflicting roles that led to specific information about the participants' decision-making processes.

\subsection{Financial Sorting as Migration Governance}

Although securitisation of migration is often linked to ethnic constructions of migration, this research reflects different profiling practices. To understand the current securitisation of Roma migrants in the United Kingdom, we first need to understand the correlations between ethnicity, surveillance and the new geopolitical incentives of the neoliberal western countries. Lyon (2013) notes that neoliberal European societies have developed a new understanding of control in the form of social sorting through technocratic bureaucracies. Thus, the securitisation of Roma migrants is not a direct result of ethnic governance, but rather an outcome of existing neoliberal market dynamics that characterise the political landscape in contemporary Europe (Van Baar 2011). Neoliberalism should be understood as both "a set of policy programmes that deregulate political government" and "a conservative liberal political movement" that bases its ideas on neoclassical economics (Van Baar 2012: 1292). Based on Foucault's notion of governmentality, many scholars (Lemke 2001; O’Malley et al. 1997; Rose and Miller 1992; Van Baar 2012) have evaluated neoliberalism as "a way of explaining the establishment and exercise of political power, one in which the concept of government is broader than management by the state; that also involves the regulation of populations through multiple institutions and technologies in society" (Mitchell 2006, p. 390). This governmentality concept has become the core of several securitisation theories that explain the expulsion and selection of migrants in the European context.

Recently, neoliberal state recognition of migrants has been based on legal economic activity and social citizenship rather than legal citizenship. It is also symbolised in the context of the European migration and integration debate, where there are vigorous disagreements about the meaning and extension of "social rights": how much should they be contingent on productive behaviour and who should be covered by which member state? Within the contemporary hierarchies of work, the functioning of borders has less to do with the geopolitical delineation of sovereign prerogatives (i.e. the power to exclude non-citizens from access to a state's territory) and more to do with the attempt to control, select and govern specific categories of people at a distance (De Giorgi 2012). A key element of this geopolitical selection process is the social contract between the state and the responsible citizen who accepts the social economic preconditions. As I will explain, this contract-based thinking holds welfare applicants responsible for losing or earning their rights to social benefits (Yeatman 1998).

Making responsibilisation the fundamental principle of this neoliberal welfare approach (Goddard 2012) justifies the selection of unproductive groups, who are seen as unwilling to integrate and participate in the host society. In the case of CEE 
migrants, this participation is generally measured in labour market participation and by the level of dependence on state funding. Individuals' labour market positions serve as a symbol of economic participation in a neoliberal society which determines who should be "sorted out" from productive taxpaying society. In this context, social benefits are not a right of those who are in need, but are financial provisions that must be earned. Local authorities in London assert disciplinary power by assessing economic success as a key aspect of social sorting and maintaining social order in their boroughs. In short, social benefits come to play a significant role in migration control (Gill and Law 1989; Strange 1988) and their distribution is underpinned by a discourse on moralising, responsibility and securitisation of the poor. Consequently, this governance model normalises the social insecurity and exclusion of "undeserving benefit claimants" based on economic performance.

To combat the perceived economic threat of benefit tourists to the national welfare system, the UK government has initiated new security measures intended to differentiate the "good" or productive citizens from the undesirable "passive" citizens. Social and spatial exclusion is based on financial determinants that serve as a functional realm that precludes inclusion of the unproductive others (Halfmann 1998).

Before we look at how these welfare-service-based financial monitoring structures facilitate the control and selection of Roma migrants, we need to understand how governing bodies invent incentives that try to induce undesired groups to voluntarily leave the country. Authorities commonly use financial restrictions to restrict the incoming mobility of undesired migrants or to foster their outgoing mobility, thus regulating and controlling unwieldy flows of people. As Hyndman (2012: 245) explains:

The idea of migrants as a vector of insecurity prevailed, creating potent fear that could be used for draconian measures. The biometric management of "insiders" and "outsiders" with its assemblage of new laws, policies and control practices render geopolitics and biopolitics inseparable.

State incentives are coded in different panoptic modalities, as tax credit regulations, to guide people on the move. As the Brexit debate proves, this apparatus of control and surveillance is frequently used as spatial disciplinary technology in the EU, where no visa regulations are in force for European citizens (Deleuze and Guattari 1987). Legal borders for population selection are thus intertwined with an internal selection based on labour participation, and with avoiding and expelling the unemployed, welfare-dependent newcomer. UK border control is thus facilitated by social economic surveillance which controls and disciplines transnational movement of the poor in EU. In such a harsh policy context, those who experience poverty are characterised "as "culpable actors' at risk of 'moral hazard" (Mead 1997: 19).

Accordingly, social security and immigration policies are increasingly intertwined within the surveillance practices of member states, blurring the line between welfare and crime control measures. Online monitoring practices, such as the use of data analysis software, are taking new forms in technocratic bureaucracies and changing the means of interaction between newcomers and administrative bodies. 
As I will argue, these neoliberal incentives intertwine with the social construction of Roma ethnicity, but first I should clarify how policymaking uses the ethnic connotations produced by academics and non-governmental actors based on economic features.

\subsection{Producing, Challenging and Transmitting the Ethnic Frame}

Access to governmental support (e.g. eligibility for social benefits) is based on definitions related to the social construction of different groups who are in need. When ethnic connotations are linked to economic deprivation, these references become part of the welfare construction of deserving citizens used in geopolitical control strategies. Today's Roma are the contemporary inheritors of the Gypsy legacy, an identity that has been historically fabricated based on different political interests. Thus, the first question is how Roma migrants have been constructed as a needy population, and how professionals, academics and NGOs have contributed to this process.

Although Roma political advocacy groups draw attention to the structural exclusion of Roma from political decisions and outcomes, many Roma intellectuals distance themselves from politics in fear that the ethnic frames they would represent would contribute to their personal exclusion. Hemelsoet and Van Pelt (2015) criticise how the "ethnicisation" of Roma identity in policy measures influences the way mediators contribute to the construction of Roma identity and how the 'use' of these connotations reinforces stigmatisation schemes. A common denominator in these political narratives is the conviction that the Roma face a set of special problems: spatial segregation, discrimination, low educational attainment and intergenerational poverty (Sigona and Vermeersch 2012). As Kostka (2015: 81) explains:

It is this understanding that is most pronounced in policy literature, stubbornly isolating questions concerning characteristic features of contemporary European society from questions pertaining to the living conditions of Roma communities.

Activists and NGOs use ethnic frames "to mobilize potential adherents and constituents, to garner bystander support, and to demobilize antagonists" (Vermeersch 2003: 885). This has had a major impact on recent assumptions about Roma migrants moving westward. Stakeholders like NGOs mobilise specific narratives as conscious strategic efforts by groups of people to fashion a shared understanding of the world and of themselves that "legitimate and motivate collective action" (McAdam et al. 1996: 6). Yet, NGOs and academics often ignore less visible subgroups if they do not fit into the socially constructed image of Roma ethnic minorities. Since the Roma community is quite diverse and fragmented, these narratives are not appreciated by those who cannot identify themselves with these realities (Vermeersch 2003). Considering these processes of ethnic framing, we need to understand how 
recent Roma ethnic categories are formed and implemented by representatives in the political arena.

The concept of the Roma "benefit tourist" is constructed by a political framing that was meant to draw attention to ethnic discrimination in Europe. However, policy guidelines have often been based on an essentialist, one-sided image underpinned by normative contentions about the causes of Roma poverty and marginalisation that contributed to such opportunist ethnic images. As Kostka (2015: 87) explains:

While policy-makers rely on empirical assessments to formulate the definitions of Roma exclusion, these assessments tend to be mediated by the existing cognitive and moral maps that orient their actions and routines. In turn, these politically accepted definitions legitimize a specific course of action, even if it is not needed or demanded by the final beneficiaries.

For example, the creation of the EU Framework for National Roma Integration Strategies up to 2020 (European Commission 2011) marks a significant step in the politicisation of Roma identity by increasing the number of initiatives, projects and programmes explicitly targeting Roma. This has affected social solidarity by disconnecting and distancing Roma from their fellow citizens. Such political tendencies differentiate Roma mobility from other intra-European movements and justify specific measures in host countries. The social and academic construction of Roma ethnicity designed by stakeholders as activists and politicians in this field is not only victimising, but these narratives also strongly contribute to existing images of welfare-dependent Roma on the margins of every European society.

At the same time, language interpreters, who often play the role of cultural mediators coming from the same sending countries, also transmit ideas and expectations that have direct implications for the interactions and the long-term policies developed in local bureaucracies. These interpreters often describe Roma as vulnerable, underdeveloped, welfare-dependent people who are living outside the law and society. When interpreters stress the vulnerability of Roma to victimisation of organised crime - or emphasise their involvement in human trafficking - these descriptions can have implications for crime control measures and the definition of a threat in the host communities. Some interpreters have even suggested that recent human trafficking laws in the UK could be applied as a migration control technique to exclude suspicious groups. Others have said that social workers seem to apply the rules more strictly to unwanted, impoverished Roma to make them move to another borough. As Pasquetti (2013: 446) notes:

[These discourses] which (re)produce fear among the public at large, are routinely mobilized by state officials to justify practices such as the increase in covert policing, the adoption of "pre-crime" national security measures, and the use of military agencies in policing incorporated people including citizens.

By referring to Roma in terms of criminal networks, mobile outsiders or welfare shoppers, these transmitted fears operate as forces at the intersection of macrostructures and micro-interactions (Barbalet 1992; Scheff 1994). 


\subsection{Passing the Virtual Sally Port: Coping Strategies of Roma Newcomers}

Western EU member states are shifting their bureaucracies towards a neoliberal business-like structure which is also reflected in the progressive incorporation of private organisations in social services. These organisations are increasingly subjected to efficiency-oriented practices, targets and limited discretionary powers. The changes in social service practices have altered the role of bureaucracies in the surveillance society. "Welfarism" has turned into targeted policing of the unemployed in which socially dependent newcomers are subjected to strict controls and sanctions. These processes are meant to control transnational mobility and prevent financial abuse.

The digitalisation facilitates new geopolitical tools for population control by electronic governance in which selection parameters are independent of nationality and ethnicity, but profile people based on economic status. Service users are thus encouraged to adapt themselves to the demands of the neoliberal labour market. Likewise, generations of newcomers develop suitable strategies to find their way through these procedures by manipulating, bypassing or hiding from these techniques of governance (Woolford and Nelund 2013).

Although expressions like "welfare tourists" and "benefit shopping" are used to describe foreign benefit claimants, living on welfare in a foreign country is a life of uncertainty. While the UK is often described as a welfare paradise, benefit claims are regularly suspended or ignored, and applicants feel subjected to an asymmetric surveillance system in which the service providers have more data about them than they have about themselves.

Foreign benefit applicants face numerous obstacles. Claimants need to prove their address to apply for a National Insurance number. Bank accounts are required for every benefit application, but it is difficult to get one without proof of income. While a migrant must regularly pay rent from the time of arrival, Housing Benefit is only available to people who have a job or receive Jobseeker's Allowance. However, Jobseeker's Allowance is only available to foreign applicants who have passed the National Habitual Residence test. This test requires proof of residence in the UK, so migrants are unable to claim anything in their first 6 months. The complexity of these interdependencies is not only interpreted as an obstacle, but as a bureaucratic fringe space where well-informed newcomers are able to circumvent restrictions to become entitled to benefits.

\subsubsection{Tax Credit Procedures: The Castle of HMRC}

The bureaucratic fringe between the content of online databases and the real circumstances of applicants can be explained by digitalised bureaucratic dysfunctions. Private sector and e-commerce surveillance methods prove dysfunctional when 
adapted to e-governance. ${ }^{2}$ The problem lies in their different objectives: public administration is concerned with the well-being of society, while e-business strives to maximise profit and increase market share (Lau 2006). Furthermore, information manipulated within an e-government process should be treated with a higher level of sensitivity than in a commercial business, and there is no need for the same level of standardisation and optimisation of processes as in a commercial business (ibid).

One such dysfunctional system is the administration of tax credit claims by the HMRC that become important for CEE migrants. These tax credit claims, which are designed to subsidise low-income taxpayers, became more popular after eligibility for Jobseeker's Allowance and Housing Benefit was restricted in 2014. However, applicants encounter difficulty in claiming these tax credits as these online application systems are facilitated by targeted surveillance algorithms that screen foreign claimants by treating them as fraud suspects.

The barriers start with the lack of face-to-face contact with advisors, which makes it more difficult for applicants to explain their circumstances. There are several inquiry centres where applicants can make free phone calls about applications, but doing so can be a stressful, expensive and time-consuming process. Each phone call starts with control questions. If the applicant is unable to answer the questions, the officer ends the conversation. Applicants know that they will be asked to provide their name and National Insurance number, but they can get confused when suddenly confronted with extra control questions. Although applicants are usually aware that these questions are designed to protect them from fraud and exploitation, they experience them as a barrier, since understanding and answering requires the assistance of an interpreter. Some of the interviewees were convinced that this process is set up to render filing claims more complicated and prolong the process in order to discourage applicants from following through.

Applicants can also apply for tax credit online, which requires them to fill in an online form, sign it and submit it to the HMRC data centre. Local brokers, such as friends or landlords, often help applicants by supplying them with the "right answers' to satisfy entitlement screening parameters. Unlike Jobseeker's Allowance applications, these processes do not deal with claimants as individuals, but rather rely on the data that they share online. This makes it more attractive for applicants seeking to hide information, as these data collection methods generate gaps between real and "uploaded identities". This is what happens in the case of child tax claims.

\subsubsection{Child Tax Credit Claims: Identity Management Online}

Formally, the child tax credit is a weekly payment to low-income families for the care of children. In practice, children are verified by their identity documents, which are submitted to HMRC by their school or general practitioner. Many aspects of the

\footnotetext{
${ }^{2}$ E-government refers to the delivery of national or local government information and services to citizens via the internet or other digital means. See Palvia and Sharma (2007).
} 
claim are interrelated and interdependent, so claimants try to avoid communicating any changes in their circumstances. For instance, a family that moves to another borough is required to inform HMRC, as the new council tax credit is determined based on the new property. This can lead to benefits being suspended or the household losing its Housing Benefit, which can cause debts and anxiety. Children must also be re-registered in the new borough, which affects child tax credit payments.

Informants reported using various strategies to keep and even increase their child tax credit payments. For instance, some "buy" an address to stay registered in their old borough. This allows them to keep their children in school, which is essential to preventing the school from informing HMRC about the change in circumstances. Benefit-dependent migrant families not only move between boroughs, but sometimes even across national borders. Transnational mobility can involve making benefit claims in more than one country and concealing transnational movements to prevent benefits from being cut.

Home-schooling allows parents to move back and forth with their children while keeping the children registered in the UK. When children attend school, parents risk being fined if they take their children out of school without notice. One interviewee was forced to move back to Hungary with her children, but she was able to keep her children registered at school in London by continuously updating the head teacher and postponing the date of return. Keeping the children enrolled in school not only ensured that they received their tax credits but also served as proof of habitual residence, making them eligible for a council house. As she explained:

\footnotetext{
It is quite restricted now, but there are still some back doors. In my case, I have been registered [in the UK] since 2011, but I was not living here from the beginning. Actually, I was coming and going, but this country has paid child tax credit from 2011, and when I claimed the Housing Benefit, they paid it! They pay everything as they are convinced that I am a resident here. Because they are in the EU, there is free movement; no stamps, no nothing about my trips back home [no trace of border crossing].
}

By circumventing the system, she could claim child tax credit and child benefits in the UK and Hungary. In the UK, she applied for welfare under the children's father's name; in Hungary, where her children are registered for home-schooling, she applied under her name.

The application process for child tax credit is one of the most common areas of fraud. Members of migrant networks can use their EU citizenship to their advantage, by drawing on differences in state-specific traditions about surnames or taking advantage of the lack of EU databases registering foreign children. Some claimants apply for child tax credits for their relatives' children. One interviewee felt exploited by her own father, who claimed child tax benefits for her daughters. Others told of filing claims for their siblings, or even for children who had passed away:

Many are handing in papers for someone else's kid to receive these weekly payments. When their own kid turns 18, they already have three children under their name [not relatives, but registered as their own children]. It does not appear that it is not his child. I see these things because we fill out some office papers and the surnames are never the same. And then there are those who take the money after a child is dead. For example, the child might have died long ago, but the birth certificate still exists, and they use it here in the UK. 
This quote illustrates that many participants have extensive knowledge about how to become eligible for welfare provisions or how to increase their income without regular employment. Such information circulates on Facebook, on forums for newcomers and in private conversations (Nagy 2018a). Many of the claimants do not see their child tax application as fraudulent, especially when extended families are taking care of the children. Others fear repercussions and debt due to overpayments. Roma newcomers acquire such knowledge from other claimants, like their employers or landlords. Those landlords see sharing information about avoiding bureaucratic barriers as support and a guarantee of rent payment.

Informal "brokers" also make a living from the commodification of information. Agents who operate in the grey market usually combine different tasks, and there is a blurred line between consensual and predatory relationships. Information, complex applications and 'favours' like informal interpreting services can cost a newcomer up to £200. Newcomers also must pay rent, housing deposits and travel costs, all of which is often organised by these brokers. Since legal aid is not available to these migrants, they depend on such agencies and often acquire debts. These restrictions increase the role of middlemen who have local connections and help newcomers pass through the sieve of the welfare sorting machine.

\subsubsection{Hide and Seek: HMRC's Electronic Monitoring Mechanisms}

The value of identity has structurally changed in digitalised societies. Technological developments in authentication, such as the use of biometric data, are hailed as the future of security and crime prevention. Such assumptions regarding the prevention of data abuse presuppose a binary distinction between victims and perpetrators, the latter being involved in online data theft and the former uninformed about the risks of identity fraud and unaware of the exploitation of their personal data. However, this distinction is not clear cut: although it may lead to effective prevention measures, it obscures those who intentionally engage in data abuse (FPEG 2007). Though victims and fraudsters are often defined in oppositional terms, there are many overlaps. However, the blurry line between the two could be defined by the level of involvement, investment and relative experience of benefit or loss. Without empirical data on the relative experience of victims, we cannot understand the value of identity fraud. Although the risk of tax overpayment is high, it still seems to be beneficial for foreign applicants, particularly in benefit claims in a foreign country.

Identity fraud, especially for child tax credit applications, usually involves the unlawful use of another person's details for gain or to avoid an obligation (Pascoe et al. 2006). This type of fraud can cover a broad range of methods that vary according to the use of the other person's details. ${ }^{3}$ Through online flows of information,

${ }^{3}$ For additional definitions of identity theft, see http://www.identitytheft.org.uk. 
even those who stay the country of origin can learn about living conditions abroad and gather information about how they, as EU citizens, can access social provisions in different member states. When EU citizenship becomes a form of capital, it can easily be commodified in the form of identity documents.

Identity theft used for identity fraud is defined as the misappropriation of another person's identity (e.g. name, date of birth, current or previous addresses) without his or her knowledge or consent, or when a perpetrator decides to simply provide an agency with false personal information (Summers et al. 2014). Applicants who are considered victims of fraud can be aware of the value of these data and might want to profit from such activities. Likewise, "intermediaries, who are mostly defined as fraudsters by law, are not necessarily seen as perpetrators" (Lacey and Cuganesan 2004 , p. 245) but they are often members of the same community they "serve" (Shover et al. 2003) and are seen as mediators who exploit the gaps in foreign welfare bureaucracy.

In the case of British benefit fraud cases, the most efficient offline approach is "selling a dream". Brokers offer something that promises profit or above average returns. As Titus (1999) argues, the lure of something absurdly cheap or lucrative is integral to many fraud "come-ons". The major factors in identity fraud are relying on the originality of the documents and on technical conditions of control measures that enable authentication of the data.

\subsection{Eluding Social Sorting by Identity Fraud Online}

In my fieldwork, I observed three types of identity fraud. In the first common form, immigrants use family members' documents to claim government benefits (illustrated by the child tax credit fraud cases). The second form of identity fraud involves migrants who exploit their extended networks and act as intermediaries for newcomers, recruiting people in their home country who are willing to provide identity documents. Those newcomers do not move to the UK seeking employment, but only travel there to sign applications and register for a National Insurance number. They then return to their home country and wait for their monthly payments. Some receive payments from the middlemen, who collected their monthly benefits. Others receive nothing, but they usually do not blame the middleman because they assume that their application was rejected. Extensive knowledge about application methods develops in relatively small communities in sending countries. In Hungary, for example, identification methods have become common knowledge in networks of marginalised young adults. This knowledge, coupled with growing socioeconomic problems, leads to the third and most interesting level of identity fraud. This involves local households selling their children's documents (e.g. birth certificates) for use by other families in child tax credit applications abroad. These practices are common in villages with extended networks in London or Manchester: 
My sister-in-law's husband asked me if I wanted to go to England to make some money. After Canada, I thought it might work out better and he has been living there for a long time now, making a lot of money with his brother, so he promised to get some benefits for us. $\mathrm{He}$ said it is easy money; we just need to go there for a few weeks and we can get 200,000 Forint [€650] per month. When I gave him my passport, he gave me 5,000 Forint [€16], but that was it. We drove there and I lived in their house with some other guys. They gave me a job in construction, but they didn’t give me any money, or only something like $£ 5$ per hour, but the others said that the company paid us $£ 8$ per hour. He helped me get a National Insurance number and apply for a bank account, so I gave him my children's birth certificates and all the other documents he asked for. I never got my bank card and I never received any money. I haven't lost anything though. I want to go back, and now I know now how to do it. I know they were taking my benefits, but what can they do with this [with the documents and his bank card]?

The applicants selling their documents know the UK procedures for social provisions. Interestingly, these claimants do not define these contracts as 'selling' their data, but rather as investing in future welfare benefits from abroad to avoid future debt. Even if they receive no benefits after selling their documents, they still consider it a good decision to commodify their data, as they have not experienced any direct loss. Their data is mostly used to apply for social benefits from foreign governments, which the sellers do not view as a crime.

After enrolling in the UK system, benefit fraudsters apply for financial services. These services require information such as first names and surnames, date of birth and place of residence. In some cases, these details are checked against databases containing personal data to identify identity theft. The components of such initial legal identity data are the most relevant for government institutions. They are also supplemented by biographical elements, which claimants construct over time to support this authentication method (FPEG 2007).

Legal proof of identity is usually the responsibility of the state. However, the type and quality of identity documents issued by governments varies. This is becoming more problematic with the introduction of biometric data, which entails the risk of falsification (Grijpink and Prins 2003). Fraudsters are developing new ways to circumvent controls and obtain the necessary data. These techniques include online and offline strategies (e.g. procurement fraud, lending fraud, payment card fraud) (Levi 2008).

In benefit fraud cases involving Roma migrants, the fraud is designed to be legally ambiguous and beneficial for all actors. However, fraudsters take the fewest risks and reap the most benefits. For instance, in combination with benefit claims, fraudsters sometimes take over the account of a legitimate customer and use his or her credit facilities. The victim's personal details are used to create a new bank account and then to apply for credit. In other cases, a fraudster permanently takes on another person's identity (Newman and McNally 2005). Identity fraud is even more sophisticated in cases where information is used to secure "breeder" documents such as birth certificates. These are used for multiple applications for credit cards, loans and benefits, securing credit that is never going to be repaid (Gordon and Willox 2003). 
The interviewees were aware of the risks they take by selling their documents, but they are also aware of the limitations of international law and cooperation. They often do not intend to stay in the UK, so they do not care if their actions have consequences for them there. Still, these commodification methods illustrate several recent problems in identity fraud legislation. According to Muller (2004), citizenship in western societies is being decomposed into "identity management". This shift is exemplified by a change in focus from questions of entitlement and rights, and the attendant cultural and ethnic attributes of citizenship, to questions of "verifying/authenticating 'identity' for the purpose of access to rights, bodies, spaces, and so forth" (ibid.: 280). Also, there is no EU-level legislation that specifically addresses identity theft (Mitchison et al. 2004). Member states have conflicting interests and differences in identification practices, credit card use, political systems and legal cultures (Grossman 2005).

Diversity in legislation and welfare provisions between different member states leads to commodification practices, which the marginalised citizens of poorer European countries exploit to survive. It is erroneous to assume that these actors are unaware of the risks they take: quite the opposite, they are conscious of the (in) effectiveness of punishment. As long as they receive benefits from these documents, they experience their involvement as profitable. They do not blame the recruiters, because it means immediate income for them. Even if some have negative experiences with fraudsters, they keep trying to invest their documents via others familiar with foreign procedures.

\subsection{The Reality Gap}

According to the classical interpretation, a victim of identity fraud is someone whose identity is abused because a fraudster is profiting from them. In the transnational mobility context, these roles are fluid over time. Individuals who voluntary sell their data actively participate in these applications and thus can be simultaneously defined as victims and perpetrators. It is unclear whether biometric technology or other data industry measures could actually reduce the incidence of identity crime. Critics have argued that instead of making changes in the identification processes, there should be a focus on the role of different actors and on altering the processes that shape these activities. The assumption that biometric data is infallible lulls authorities into thinking that they have found a solution to one of the basic problems of modernity, which has acquired a particular salience in today's globalised world: the problem of suspect identities (Cole 2009). As Lyon (2010: 607) suggests, "showing a token of legitimate ID is now a basic condition for the exercise of freedom". This points not only to how biometric technologies limit movement by producing "disqualified bodies" (Muller 2004), but also to the advantages such technology can offer to those with the right tokens: the globally mobile "kinetic elites" (Adey et al. 2014). Identity controls are, thus, not only fraud prevention 
measures, but also mobility controls on the poor. In this context, Aas (2011: 341) notes that practices of transnational surveillance:

[Unlike more] inwardly-directed national surveillance, revolve around alliances between "states like us" and protecting the public, which is no longer defined exclusively as the citizenry of the nation state. On the level of political discourse, these practices seem to aspire to notions of "pan-European and cosmopolitan citizenship".

However, various social groups (citizens, sub-citizens, supra-citizens and noncitizens) hold unequal positions in terms of the degree of surveillance they are subjected to, ranging from extreme deprivation to great social privilege (Nagy 2018b). This inequality reveals the inadequacy of the traditional liberal notion of citizenship as the springboard for articulating a discourse of rights.

Social sorting policies have been included in intra-European control measures based on data surveillance of benefit-dependent migrants. These data collections serve to objectively and efficiently select applicants based on parameters of welfare eligibility. However, such selections represent the neoliberal values of productivity. Instead of supporting poor unemployed applicants, these profiling systems are excluding them based on their financial capabilities. Such a selection method based on the suspicion of welfare claimants has been defined as a new geopolitical measure - the funnel of expulsion - to keep the undesired migrants away. However, such mobility control is overestimated, since the targeted ones can challenge such a mechanism and adapt to the selection parameters, especially in a virtual environment.

Surveillance is an active process with various levels of interaction between the surveyor and the survey object. The choice to apply for tax credits instead of welfare benefits represents a change from face-to-face interaction to virtual bureaucratic dialogues that shape the techniques of control and selection. Although virtual bureaucracies require internet literacy, they also provide a special identity-making space since the real person is no longer included in the digitalised interactions. This virtual space enables newcomers who are targeted for social exclusion to turn their virtual characteristics into those of a deserving productive citizen.

The use of electronic applications changes the process of "social sorting" and the tactics claimants use. Benefit applicants have always been monitored by service providers, but new digital systems include screening moments that push benefit applicants towards participation in the labour market and restrict their eligibility. Data about claimants is stored in databases and analysed by algorithms that calculate the "risk" of welfare dependency, fraud or long-term unemployment. This makes it more difficult for applicants to prove their eligibility, and drives them to search for loopholes in the system to avoid selection mechanisms.

The digitalisation of the service provision system creates a gap between the data on individuals and the actual person that data is meant to identify. Claimants in a virtual application system are less likely to represent themselves accurately, but instead attempt to come as close as possible to an "ideal type", based on the requirements for benefit entitlement. In this digital dialogic process, screening programmes and welfare applicants are continuously changing the parameters of screening requirements, which in turn triggers more restrictive application procedures. 
These cat and mouse games between the claimant and the bureaucracy create an increasing reality gap between the claimant's real identity and the "dividual" who is translated into data based on specific parameters. Databases are filled with the altered personal information provided by those who feel targeted by local bureaucracies. These mutated profiles lead to unpredictability and inconsistency in spatial sorting strategies, increasing distrust among benefit claimants who, as a result, become even less transparent. Although screening mechanisms like spidergrams are increasingly included in databases, the algorithm that is supposed to filter claimants is cheated. These retargeting and restrictive policies both underestimate the participative skills of applicants and overestimate the capacities of digitalised bureaucracies.

As these processes are fuelled by welfarist political lobbies, service providers and applicants are suspicious of one another and keep each other in constant confusion by selecting information in online or offline interactions. I found that both claimants and service providers are involved in transgressive actions related to application procedures. The tightened managerialist norms that restrict professional considerations to a risk-screening analysis illustrate how individual considerations still affect decisions about claims. The reality gap facilitated by the digitalisation of welfare services provides a new space of operations for both civil servants and applicants.

The monitoring of applications and the selection of benefit recipients as political technologies of social sorting are thus carried out on several levels. It is not just an audit of recipients or a surveillance of eligibility criteria, but an extended consolidated verification procedure based on joint databases and, in some cases, maintenance enforced by computer assistance. As the examples illustrate, these notions are constructed as governmental incentives for profiling "the bad foreign opportunists" versus "the good citizens" who deserve support and protection from the state. These disincentives for foreign benefit claimants can also be traced in other screening instruments. These ongoing transformations of modern penal practices such as benefit sanctions reflect the capitalistic need to carve a docile and hardworking workforce out of the unruly, undisciplined and sometimes riotous "dangerous classes" constantly generated by capital itself as a by-product of its movement of creative destruction (Schumpeter 1942).

\subsection{Conclusion}

As the case of benefit applicant migrants illustrates, digitalisation of national bureaucracies opened new doors for migration governance. Diversity management of EU member states is now defined in financial terms, replacing ethnic constructions of social inclusion with financial parameters. Post-modern modalities of migration control are present in all bureaucratic practices in EU member states, and 
surveillance practices do not only affect Roma welfare applicants. This study focused on how several profiling mechanisms that are associated with ethnic discrimination against welfare-dependent groups are shifting into neoliberal financial discrimination. It shows that Roma migrants who experience institutional discrimination based on financial connotations still explain these financial profiling mechanisms as ethnic targeting and respond to them accordingly. As their knowledge about the data collection methods of service providers increases, excluded groups who are aware of the preconditions of service providers' digital selection methods learn and invent tactics to circumvent legal restrictions. Although these newcomers are often framed as a dependent, uneducated and traditional minority, they successfully develop knowledge about the weaknesses and advantages of digitalised bureaucracies and adapt to the parameters of the desired applicant. Coping strategies are differentiated on a broad scale in which identity management plays a vital role. Therefore, behavioural modifications should be explained with different decision-making processes than in the case of UK nationals who are subjected to similar profiling and sanctions. To fit in to their host country, many Roma use economic coping strategies that also sustain ethnic invisibility. Hiding the Roma ethnicity is understood as a technique for gaining social and cultural inclusion.

Benefit tourism is a misconception. Roma newcomers are moving towards Western Europe with a range of aspirations, especially to escape ethnic stigmatisation. However, ethnic targeting by NGOs and market-oriented advocacy work contribute to existing ideas about marginal Roma groups that justify targeting mechanisms. These neoliberal selection methods shift discriminatory practices from ethnic parameters to the financial capabilities of applicants. Roma newcomers who settle abroad are constantly monitored by their environment: they are under high expectations from their family networks and are living under the gaze of welfare surveillance. Theirs is a life of transgression on the edge of moral deservingness and legal eligibility, constructed by a hidden identity.

This study reveals that the objectivity and effectiveness of digitalised surveillance practices are overestimated and that calculative effects of surveillance awareness are underestimated in the field of welfare provisions in the UK. Due to conflicting values in welfare provisions, managerialist neoliberal service providers cannot act according to the norms of a welfare state and adopt competitive market-oriented principles. These production-oriented notions "from welfare to work" are shifting the role and strategies of contracted service providers that control and sanction the unemployed. Unattractive migrant groups, often seen as "benefit tourists" and associated with benefit shopping, are meant to be targeted and excluded from the welfare system and forced towards the labour market. However, instead of leaving or avoiding service providers, many applicants stay. 


\section{Bibliography}

Aas, K. F. (2011). 'Crimmigrant' bodies and bona fide travelers: Surveillance, citizenship and global governance. Theoretical Criminology, 15(3), 331-346. https://doi. org/10.1177/1362480610396643.

Adey, P., Bissell, D., Hannam, K., Merriman, P., \& Sheller, M. (2014). The Routledge handbook of mobilities. London: Routledge.

Barbalet, J. M. (1992). A macro sociology of emotion: Class resentment. Sociological Theory, 10(2), 150-163. https://doi.org/10.2307/201956.

Cherkezova, S., \& Tomova, I. (2013). An option of last resort? Migration of Roma and nonRoma from CEE countries. (Roma Inclusion Working Papers). Retrieved from United Nations Development Programme website: http://www.undp.org/content/dam/rbec/docs/Migration-ofRoma-and-Non-Roma-from-Central-and-Eastern-Europe.pdf

Cole, S. A. (2009). Suspect identities: A history of fingerprinting and criminal identification. Cambridge, MA: Harvard University Press.

De Giorgi, A. (2012). Punishment and political economy. In R. Sparks \& J. Simon (Eds.), The SAGE handbook of punishment and society (pp. 40-59). London: SAGE Publications.

Deleuze, G., \& Guattari, F. (1987). A thousand plateaus (B. Massumi, Trans.). Minneapolis: The University of Minnesota Press.

Erjavec, K. (2001). Media representation of the discrimination against the Roma in Eastern Europe: The case of Slovenia. Discourse and Society, 12(6), 699-727. https://doi.org/10.1177 /0957926501012006001.

European Commission. (2011). An EU framework for national Roma integration strategies up to 2020. Brussels: European Commission. Retrieved from http://ec.europa.eu/justice/policies/ discrimination/docs/com_2011_173_en.pdf.

FPEG (EU Fraud Prevention Expert Group). (2007). Report on identity theft/fraud. Brussels: European Commission. Retrieved from http://ec.europa.eu/internal_market/fpeg/docs/ id-theft-report_en.pdf.

Gill, S. R., \& Law, D. (1989). Global hegemony and the structural power of capital. International Studies Quarterly, 33(4), 475-499. https://doi.org/10.2307/2600523.

Goddard, T. (2012). Post-welfarist risk managers? Risk, crime prevention and the responsibilization of community-based organizations. Theoretical Criminology, 16(3), 347-363. https://doi. org/10.1177/1362480611433432.

Gordon, G. R., \& Willox, N. A., Jr. (2003). Identity fraud: A critical national and global threat. New York: Economic Crime Institute, Utica College. Retrieved from https://www.lexisnexis. com/presscenter/hottopics/ECIReportFINAL.pdf.

Grijpink, J. H. A. M., \& Prins, J. E. J. (2003). New rules for anonymous electronic transactions? An exploration of the private law implications of digital anonymity. In C. Nicoll, J. E. J. Prins, \& M. J. M. van Dellen (Eds.), Digital anonymity and the law. Tensions and dimensions (pp. 249269). The Hague: T.M.C. Asser Press.

Grossman, W. M. (2005, January 19). Identifying risks: National identity cards. Lecture delivered at the University of Edinburgh. Retrieved from http://www2.law.ed.ac.uk/ahrc/script-ed/ vol2-1/idcards.asp

Halfmann, J. (1998). Citizenship universalism, migration and the risks of exclusion. The British Journal of Sociology, 49(4), 513-533. https://doi.org/10.2307/591286.

Hemelsoet, E., \& Van Pelt, P. (2015). Questioning the policy framing of Roma in Ghent, Belgium: Some implications of taking an insider perspective seriously. Social Inclusion, 3(5), 148-160. https://doi.org/10.17645/si.v3i5.236.

Huysmans, J. (2000). The European Union and the securitization of migration. JCMS: Journal of Common Market Studies, 38(5), 751-777. https://doi.org/10.1111/1468-5965.00263.

Hyndman, J. (2012). The geopolitics of migration and mobility. Geopolitics, 17(2), 243-255. https://doi.org/10.1080/14650045.2011.569321. 
Kostka, J. (2015). Implementation of Roma inclusion policies: Why defining the problem matters. Social Inclusion, 3(5), 78-89. https://doi.org/10.17645/si.v3i5.231.

Lacey, D., \& Cuganesan, S. (2004). The role of organizations in identity theft response: The organization-individual victim dynamic. Journal of Consumer Affairs, 38(2), 244-261. https:// doi.org/10.1111/j.1745-6606.2004.tb00867.x.

Lau, M. H. (2006). Research on the relationship between risk perception, risk propensity and risk-reducing decision-making in an e-government environment. Unpublished master's thesis, Erasmus University Rotterdam, the Netherlands. Retrieved from https://www.pvib.nl/downloa $\mathrm{d} /$ ? id=6391917 anddownload $=1$

Lemke, T. (2001). "The birth of bio-politics" - Michel Foucault's lecture at the Collège de France on neo-liberal governmentality. Economy and Society, 30(2), 190-207. https://doi. org/10.1080/03085140120042271.

Levi, M. (2008). Organized frauds and organizing frauds: Unpacking the research on networks and organization. Criminology and Criminal Justice, 8(4), 389-419. https://doi. org/10.1177/1748895808096470.

Lyon, D. (2010). National IDs in a global world: Surveillance, security, and citizenship. Case Western Reserve Journal of International Law, 42(3), 607-624. Retrieved from http://scholarlycommons.law.case.edu/jil/vol42/iss $3 / 5$.

Lyon, D. (2013). The information society: Issues and illusions. Hoboken: Wiley.

McAdam, D., McCarthy, J. D., \& Zald, M. N. (1996). Comparative perspectives on social movements: Political opportunities, mobilizing structures, and cultural framings. Cambridge, UK: Cambridge University Press.

Mead, L. M. (1997). Citizenship and social policy: TH Marshall and poverty. Social Philosophy and Policy, 14(2), 197-230. https://doi.org/10.1017/S0265052500001886.

Mitchell, K. (2006). Neoliberal governmentality in the European Union: Education, training and technologies of citizenship. Environment and Planning: Society and Space, 24(3), 389-407. https://doi.org/10.1068/d1804.

Mitchison, N., Wilikens, M., Breitenbach, L., Urry, R., Portesi, S. (2004). Identity theft: A discussion paper. (Catalogue no. LB-NA-21098-EN-C). European Commission Joint Research Centre. Retrieved from EU Law and Publications website: https://publications.europa.eu/en/ publication-detail/-/publication/916463fb-d524-4865-b188-c34beca595f2/language-en

Muller, B. J. (2004). (Dis) qualified bodies: Securitization, citizenship and 'identity management. Citizenship Studies, 8(3), 279-294.

Nagy, V. (2018). Crime prevention, migration control and surveillance practices: Welfare bureaucracy as mobility deterrent.

Nagy, V. (2018a). Roma networks: Ethnic solidarity in an internet age?. Transnational Roma Mobilities, 158.

Nagy, V. (2018b). The Janus face of precarity-Securitisation of Roma mobility in the UK. Local Economy, 33(2), 127-146.

Newman, G., \& McNally, M. M. (2005). Identity theft literature review. (National Institute of Justice Focus Group Meeting, NCJ 210459). Retrieved from https://www.ncjrs.gov/pdffiles1/ nij/grants/210459.pdf

O'Malley, P., Weir, L., \& Shearing, C. (1997). Governmentality, criticism, politics. Economy and Society, 26(4), 501-517. https://doi.org/10.1080/03085149700000026.

Palvia, S. C. J., \& Sharma, S. S. (2007). E-government and e-governance: Definitions/domain framework and status around the world. International Conference on E-governance. Retrieved from http://www.iceg.net/2007/books/1/1_369.pdf

Pascoe, T., Owen, K., Keats, G., \& Gill, M. (2006). Identity fraud: What about the victim? Research findings. CIFAS - Perpetuity Research. Retrieved from https://www.cifas.org.uk/secure/contentPORT/uploads/documents/External-Identity\%20Fraud\%20-\%20What\%20About $\% 20$ the\%20Victim\%20Research\%20Findings.pdf

Pasquetti, S. (2013). Legal emotions: An ethnography of distrust and fear in the Arab districts of an Israeli city. Law and Society Review, 47(3), 461-492. 
Rose, N., \& Miller, P. (1992). Political power beyond the state: Problematics of government. The British Journal of Sociology, 43(2), 173-205. https://doi.org/10.2307/591464.

Scheff, T. J. (1994). Microsociology: Discourse, emotion, and social structure. Chicago: University of Chicago Press.

Schumpeter, J. (1942). Capitalism, socialism and democracy. New York: Harper and Brothers.

Shover, N., Coffey, G. S., \& Hobbs, D. (2003). Crime on the line: Telemarketing and the changing nature of professional crime. The British Journal of Criminology, 43(3), 489-505.

Sigona, N., \& Vermeersch, P. (2012). Editors' introduction. The Roma in the new EU: Policies, frames and everyday experiences. Journal of Ethnic and Migration Studies, 38(8), 1189-1193.

Siobhan, F. (2017). Theresa May will 'use Brexit to stop EU migrants claiming UK benefits'. http:// www.independent.co.uk/news/uk/politics/brexit-theresa-may-stop-eu-migrants-uk-benefitsclaim-latest-european-union-a7505311.html. Retrieved 30 Sept 2017.

Strange, S. (1988). States and markets: An introduction to international political economy. London: Pinter.

Summers, S., Schwarzenegger, C., Ege, G., \& Young, F. (2014). The emergence of EU criminal law: Cyber crime and the regulation of the information society. London: Bloomsbury Publishing.

Titus, R. M. (1999). The victimology of fraud. Paper presented to the Restoration of Victims of Crime Conference, Melbourne, Australia. Retrieved from http://www.aic.gov.au/media library/conferences/rvc/titus.pdf

Van Baar, H. (2011). The European Roma: Minority representation, memory, and the limits of transnational governmentality. Unpublished doctoral thesis, University of Amsterdam, Amsterdam, The Netherlands.

Van Baar, H. (2012). Socio-economic mobility and neo-liberal governmentality in post-socialist Europe: Activation and the dehumanisation of the Roma. Journal of Ethnic and Migration Studies, 38(8), 1289-1304.

Vermeersch, P. (2003). Ethnic minority identity and movement politics: The case of the Roma in the Czech Republic and Slovakia. Ethnic and Racial Studies, 26(5), 879-901.

Woolford, A., \& Nelund, A. (2013). The responsibilities of the poor: Performing neoliberal citizenship within the bureaucratic field. The Social Service Review, 87(2), 292-318.

Yeatman, A. (1998). Interpreting contemporary contractualism. In M. Dean \& B. Hindess (Eds.), Governing Australia: Studies in contemporary rationalities of government (pp. 227-241). Cambridge, UK: Cambridge University Press.

Open Access This chapter is licensed under the terms of the Creative Commons Attribution 4.0 International License (http://creativecommons.org/licenses/by/4.0/), which permits use, sharing, adaptation, distribution and reproduction in any medium or format, as long as you give appropriate credit to the original author(s) and the source, provide a link to the Creative Commons licence and indicate if changes were made.

The images or other third party material in this chapter are included in the chapter's Creative Commons licence, unless indicated otherwise in a credit line to the material. If material is not included in the chapter's Creative Commons licence and your intended use is not permitted by statutory regulation or exceeds the permitted use, you will need to obtain permission directly from the copyright holder.

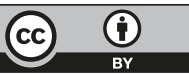

